\title{
RESEARCH
}

Open Access

\section{Views and attitudes of local people towards community versus state forest governance in Tehulederi District, South Wollo, Ethiopia}

Birhan Ali Woldie ${ }^{1}$ and Solomon Ayele Tadesse ${ }^{2^{*}}$

\begin{abstract}
Introduction: Restoring the degraded sites with vegetation cover is an optimal solution to mitigate environmental disasters. Starting from the 1980s, donor-assisted land rehabilitation activities were taking place in Tehulederi District, South Wollo, Ethiopia. Meanwhile, majority of the forests were destroyed; part of the problem was associated with the top-down approach of forest management. The challenge is, therefore, to find a system of management that can enhance the combined effect of both the community and the state. The community forestry (i.e. a forest development activity which is practiced and managed collectively by the community members on their communal land) is one such alternative. The objectives of the study were to (1) examine the views and attitudes of local people towards community versus state forests governance and (2) evaluate the management practices implemented in the community versus state forestry and their implications on the forest status and the livelihood of local people.

Methods: A structured questionnaire consisting of closed- and open-ended questions was developed to collect quantitative data from randomly selected households. Moreover, key informant interviews and focus group discussions were conducted to gather qualitative data. Descriptive statistics and multiple linear regression were used to analyze and interpret the quantitative data. The data obtained through key informant interviews and focus group discussions were synthesized and narrated using a qualitative method.

(Continued on next page)
\end{abstract}

\footnotetext{
* Correspondence: solomon.ayele1972@gmail.com

Department of Natural Resources Management, College of Agriculture and

Natural Resource Sciences, Debre Berhan University, P.O. Box 445, Debre

Berhan, Ethiopia

Full list of author information is available at the end of the article
} 
(Continued from previous page)

Results: Several socioeconomic variables significantly affected the views and attitudes of local people towards community versus state forests governance. Generally, local people had positive views and attitudes towards the community forestry. Over $83 \%$ of the respondents agreed to accept and practice community forestry. In contrast, about $70 \%$ of the respondents had negative views and attitudes towards the state forestry. The positive views and attitudes of local people towards the community forestry may be connected with the perceived benefits (e. g. infrastructure development, source of medicinal plants, wood products, and source of fodder) and the values (e.g. aesthetic and recreational) that local people expect from the community forest. However, the negative views and attitudes of local people towards the state forestry could be attributed to the fact that the community may have limited access to forests when they are exclusively managed by the government. Moreover, such forest management may aggravate antagonistic relationship between the government and local people and be manifested as forest use conflicts. The results obtained from key informant interviews and focus group discussions suggested that the community forest had a better status than the state forest. This may have resulted from the relative advantage of the community forestry to make better use of the community forest, manage it more sustainability, and contribute more equitably to satisfy local livelihoods than does the state forestry. The respondents also illustrated the dependence of local people on forests, utilization, protection, management, and silvicultural schemes implemented in the community versus state forests.

Conclusions: The findings emphasize the importance of collective decisions in forest management and governance. The intervention for a legal framework and institutional development particularly through formal recognition of local people's ownership and right over the use of forests is indispensable towards sustainable forestry.

Keywords: Environmental disaster, Focus group discussion, Forest utilization and management, Household survey, Key informant interview, Sustainable forestry

\section{Introduction}

The forests in Ethiopia are being degraded at an alarming rate of 150,000 to 200,000 ha year $^{-1}$ (EFAP 1994). Hence, restoring the degraded sites with vegetation is essential to mitigate environmental disasters in Ethiopia. Since the beginning of the 1980s, donor-sponsored land rehabilitation has been implemented in different parts of the country. South Wollo is one of the regions in northern Ethiopia that attracted the attention of some of the early land rehabilitation programmes in the country. This was partly due to the fact that the 1973 famine was associated with activities, such as deforestation and clearing of forests for crop cultivation (Admassie 1995; Pankhurst 2001; Abiyu 2005). Moreover, the famine in South Wollo had political implications in that it was taken as the fault of the regime under Emperor Haile Selassie I and was one of the immediate causes for its downfall. Therefore, the succeeding socialist government had to show concern. To start with, hillside exclosures and reforestation activities began on the basis of a food-for-work programme, whereby peasants were given grain and oil for planting seedlings, building terraces and micro-dams (Admassie 1995; Bekele 2003).

Despite the efforts made to alleviate the problems of forest degradation, the results were not impressive, especially when one considers the labour and money invested in the whole programme as compared to what was achieved. This is because little attention was given to the views and attitudes of local people towards forest conservation programmes and to identify their priorities. For example, in most conservation programmes, local people were neither consulted nor included in the planning process (Kelboro and Stellmacher 2015). Once the forest rehabilitation projects which were run by donor agencies had been completed, it was not possible for local people to shoulder the responsibility to implement and continue the objectives of those projects (Tekle 1999). According to Stahl (1990), the forest rehabilitation policy was not consultative and supportive of local people in Ethiopia, rather it was prescriptive and commandist. For instance, it only emphasized the number of seedlings planted rather than caring for the survival, management, and utilization of the planted trees. Moreover, more attention was given to the number of seedlings planted on the closed hillsides from human and livestock interferences rather than focusing on how to manage the vegetation (Bekele 2003).

Many hillside exclosures were destroyed during the transition period after the change of the Dergue government in 1991. One of the most important reasons for the destruction of hillside exclosures witnessed in 1991 in Ethiopia was the ambiguous and uncertain land use right and ownership system (Admassie 1995; Lemenih and Bekele 2007; Kelboro and Stellmacher 2015). This suggests that the land tenure system of an area negatively affects land management practices; hence, it determines the success of forest conservation. This is because clearly defined property rights can contribute 
greatly to reversing forest degradation problems. For example, Ezra and Kassahun (1988) reported that the uncertainty about ownership and rights of the use of tree plantations contributed to the low performance of forest development in Ethiopia. In many instances, farmers were not allowed to graze their livestock or cut grass inside the exclosures. Moreover, there was no coherent national forest policy, legal frameworks, and guidelines on the utilization of trees planted in the community forests (Dejene 1990). Even though farmers planted tree seedlings, they were not sure what would happen to their trees or who was going to use them later. In addition, there was no follow-up of the planted seedlings and no regular reports after the year of planting. For example, it was difficult to come up with reliable figures on the survival rate of the tree seedlings in the food for work programmes during the Dergue regime.

The government of Ethiopia has recently begun to recognize the necessity of people's participation in forest management. This has come about as a result of both local initiatives (Wily 2002), for example, the case in Tigray and Amhara regions, woodlots, and non-government-sponsored pilot projects (Lemenih and Bekele 2007). Although these forest developments are encouraging, it was observed that the implementation strategy is based on the application of state-derived rules, in order to achieve state objectives. So, it has resulted in numerous, often widespread, protests and conflicts between the local people and the state. Therefore, an important question for Ethiopia is: "is it possible to maintain good forest stand when decisions concerning on the use and management are taken through communal collective action for community objectives rather than for the state objectives? An answer to this question would be useful as a guide in developing forest management strategies and plans through the implementation of the community forestry approach.

Optimal forest management is, therefore, dependent upon views (e.g. experience and knowledge) and attitudes of local people who are naturally linked with the forest landscape and through their active participation in forest management (Tesfaye et al. 2012; Ameha et al. 2014; Kelboro and Stellmacher 2015). Various studies also noted that previous benefits and values can affect views and attitudes of local people towards forest conservation and management (e.g. Tadesse and Teketay 2017; Siraj et al. 2018). This is because values are the most important and central elements in a person's system of views and attitudes (Oskamp 1977; Woltamo 1997).

Views and attitudes are positive or negative responses of people towards a certain event (e.g. community versus state forests governance) (Jotte 1997; Kelboro and Stellmacher 2015). Thus, negative or positive views and attitudes of local people towards community versus state forests will likely affect their contribution and participation in the management of forests. Views and attitudes of local people can be affected by their behaviours (Jotte 1997; Woltamo 1997; Kellert et al. 2000). Hence, understanding how behaviour affects views and attitudes of local people is of paramount importance for conservation and sustainable utilization of forests through introducing and implementing appropriate forest management and governance, especially in developing countries, such as Ethiopia, where local people are directly dependent on forest resources to meet their needs (Tesfaye et al. 2012; Ameha et al. 2014; Tadesse and Teketay 2017).

At present, community forestry has been seen in a number of catchments/woodlots in Tehulederi District, South Wollo, Ethiopia. However, no quantitative and qualitative studies were so far conducted to justify how community forest management serves as an alternative to state forest so as to enhance the condition of the forest resources. Therefore, it is crucial to investigate the views and attitudes of local people towards community versus state forests governance. Accordingly, the following three questions were addressed in the present study: (1) Has the implementation of community forest management been a failure or a success so far? (2) If so, where has it been achieved? (3) If not, why not? One of the assumptions for this study was that the conventional approach (i.e. when forests are managed and governed by the state) to forest conservation is not effective because the forests are subjected to illegal access and/or unregulated utilization. In contrast, the community forestry approach alleviates the existing excessive pressure on forests by regulated access as the local communities become caretakers of the community forests. The objectives of the study were to (1) examine the views and attitudes of local people towards community versus state forests governance and (2) evaluate the management practices implemented in the community versus state forestry and their implications on the forest status and the livelihood of local people.

\section{Methods}

\section{Study area}

The study was conducted in Tehulederi District, South Wollo, situated in the eastern margin of North Central Massif, about $415 \mathrm{~km}$ from the northeast of Addis Ababa, Ethiopia. Bededo Kebele was purposely selected for this study because it was the only kebele in Tehulederi District that contained both community- and state-owned forests. Kebele is the smallest administrative unit in Ethiopia. Bededo Kebele is geographically located at $11^{\circ} 14^{\prime} \mathrm{N}$ and $39^{\circ} 46^{\prime} \mathrm{E}$ (Fig. 1), with an average elevation of $2350 \mathrm{~m}$ above sea level, and covers a total area of 1545 ha. It has 1035 households. The total 


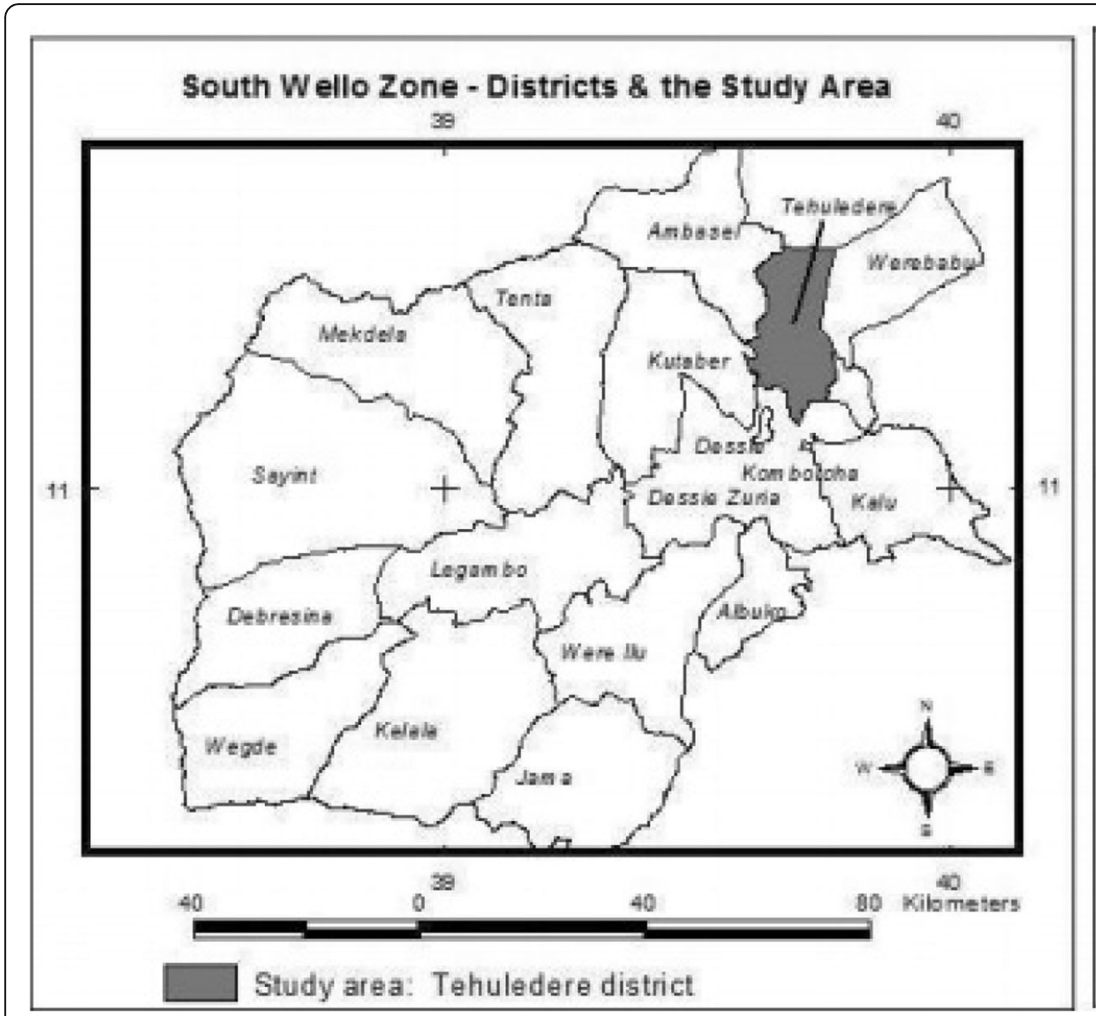

Ethiopia \& the Regional States

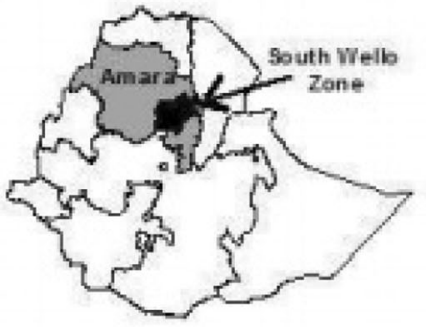

Amara Regional State and "South Wello Zone"

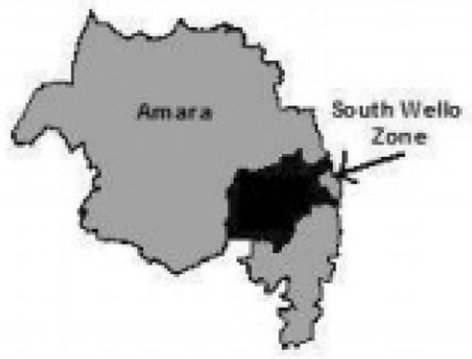

Fig. 1 Map of the study area

population size of the study area was 6199 inhabitants. The livelihood of the local people mainly depends on subsistent farming, in which livestock husbandry and crop productions play a major role. The climate of the study site is characterized by wet seasons that mostly occur from July to September (long rainy season), locally known as Kiremt, and February to May (short rainy season), locally known as Belg. There is a long dry period from the end of September to February, and a short dry spell in June (Bekele 2000). The mean annual precipitation was $1030 \mathrm{~mm}$, and the mean monthly temperature was about $21^{\circ} \mathrm{C}$ (Abiyu 2005).

The natural vegetation is broadly classified as Junipersus procera forest or dry, single dominant 'Afromontane forest' with Junipersus procera and Olea europea as the dominant species. At higher elevations, the remnants of the original Afromontane forest occur as secondary forest, with Junipersus procera, Olea europea, and Afrocarpus falcatus being the dominant tree species (Friis 1992; Bekele 2000; Abiyu 2005). The site was a pioneer area for implementing government-sponsored reforestation programme in South Wollo, which has had continuous donor support since the 1980s (Abiyu 2005). According to the records available at the local district forestry office, a total of 126 ha of forests were managed by the community. However, the remaining 761 ha of the forests were managed by the district office of agriculture.
The study site was one of the oldest vegetation restoration areas in South Wollo and was not a complete victim of forest destruction during the change of the government in the early 1990s (Bekele 2000; Abiyu 2005). Since the beginning of 1980 s, a donor-assisted hillside reforestation programme has been going on in Bededo Kebele, as one of the principal responses for alleviating the problems caused by the widespread loss of trees and forest cover. Being financially supported by non-governmental organizations, the forestry department established community nurseries and produced and planted millions of tree seedlings with community labour on communal lands (personal communication with Tehulederi District Administrative Office, March 2016).

\section{Survey procedure}

A preliminary survey was carried out to get better information about the study site and the relevant type of data to be collected. A structured questionnaire comprising closed-and open-ended questions was prepared (Tesfaye et al. 2012; Tadesse and Kotler 2016; Tadesse and Teketay 2017) that likely affect the views and attitudes of local people towards community versus state forests in Tehulederi District. On the basis of forest governance arrangements (Paudyal 1996), i.e. community and state forests, and in line with the Amhara 
National Regional State forest proclamation and regulation, community forests are defined as forests where communities do have the control over and claim ownership. However, forested areas under the direct control of the district forestry department, and without any form of collective action/participation by local people, have been considered as state forests (ANRS-BOA 1999).

Most socioeconomic-, knowledge-, and experiencemeasuring questions were measured in nominal scale and rated using $3=$ yes, unsure $=2$, and $1=$ no. Larger values expressed greater views. Age, family size, length of local residence, annual income, land size, and level of education were measured in continuous quantitative values. Views towards community versus state forests were measured using $3=$ yes, unsure $=2$, and $1=$ no, where larger values reflected positive views towards community versus state forests. To quantify the attitudes of the respondents towards community versus state forests, Likert scale was employed and rated using 5 = strongly agree, 4 = agree, $3=$ unsure, $2=$ disagree, and $1=$ strongly disagree (Cohen et al. 2000; Hren et al. 2004; Tadesse and Teketay 2017). Larger values reflected positive attitudes of the respondents either towards the community forest governance or the state forest governance or both.

To complement the household survey, key informant interviews and focus group discussions were conducted to examine the management practices implemented in the community versus state forests (Kelboro and Stellmacher 2015). The key informant interviews and focus group discussions were carried out using a checklist which addressed the themes of the dependence of local people on forests, utilization, protection, and development practices, held in community and state forests found in Tehulederi District.

\section{Data collection Household survey}

The household survey was conducted through administering structured questionnaire by interviewing households living in Bededo Kebele. The household survey is helpful to collect quantitative data. Following Tadesse and Tafere (2017) and Tadesse and Teketay (2017), the questionnaire was developed by considering socioeconomic variables, such as sex, age, family size, level of education, length of local residence, occupation type, history of settlement, livestock and land ownership, land size, annual income, accessibility to forest resources, knowledge on traditional bylaws that restrict people and/or livestock from illegally destroying the tree seedlings planted and grown in the study site, and distance between the edge of the forests and the residential area of the respondents. The questionnaire was administered to a total of 160 households. The data were collected via house-to-house interviews.

\section{Key informant interviews}

Key informants (i.e. persons who are supposed to be knowledgeable of their locality and have good knowledge (Kelboro and Stellmacher 2015) about community and state forests governance) were selected in consultation with development agents and kebele administrators. The key informants were mainly elderly men and women, religious leaders, and opinion makers in the community. The interviews were also conducted with development agents, kebele administrators, and experts working at Tehulederi District Office of Agriculture. A total of 25 individuals were interviewed through this method.

\section{Focus group discussions}

Focus group discussions were conducted with a group of individuals who were believed to be equally interested or affected by the topic being discussed. The discussion was guided by a facilitator during which group members were encouraged to talk freely and spontaneously about a certain topic, but if possible, to come up with shared views and opinions, so that opinions within the group on the issue being discussed were synthesized and narrated. The results were the outcome of the group interactions but not the views of an individual. Three focus group discussions (i.e. male group, female group, and youth group) were conducted. Each focus group contained ten members. A checklist was used as a memory guide to facilitate the focus group discussions (Kelboro and Stellmacher 2015). All the focus group discussions were tape-recorded, and short notes were also taken. The whole data were collected in May 2016.

\section{Independent variables}

Following Tadesse and Tafere (2017) and Tadesse and Teketay (2017), the independent variables were derived from the following 22 questions. These were (1) sex, (2) age, (3) level of education, (4) family size, (5) annual income, (6) livestock ownership, (7) enough grazing land, (8) shortage of fodder for their livestock, (9) want to keep more livestock than have at present, (10) length of residence in the area (in years), (11) history of settlement in the area, (12) plan to stay in the area in the future, (13) private land ownership, (14) land size (ha), (15) tree planting and growing tradition, (16) shortage of fuelwood, (17) accessibility to forest resources, (18) distance between the edge of the forests and the residential area of the respondents $(\mathrm{km}),(19)$ incentives (e.g. seeds, tree seedlings, technical supports, and credits) to plant and grow trees, (20) sufficient market to sell their forest products, (21) enough labour to manage trees/seedlings planted and grown by themselves, and (22) knowledge on traditional bylaws that restrict people and/or livestock from illegally destroying the tree seedlings planted and grown in the study site. 


\section{Dependent variables}

The two types of dependent variables were derived from the following four statements: (1) views towards the community forest governance, (2) views towards the state forest governance, (3) consent that the respondents had positive attitudes towards the community forest governance, and (4) consent that the respondents had positive attitudes towards the state forest governance.

\section{Data analyses}

Depending on the nature of the data, methods of qualitative and quantitative analyses were used to analyze and interpret the data. For example, the data obtained through key informant interviews and focus group discussions were synthesized and narrated using a qualitative method. However, descriptive statistics, such as mean, standard deviation, and proportion, were used to analyze household characteristics. Multiple linear regression model set at $\alpha=0.05$ was used to analyze and predict the values of the dependent variables. After accounting for multiple comparisons (22 tests per dependent variable) with a Bonferroni correction, $P \leq 0.002$ was considered significant. The Bonferroni correction was computed by dividing 0.05 to 22 which was equal to 0.002 . This is because Bonferroni correction is a safeguard against multiple tests of statistical significance on the same data falsely giving the appearance of significance (Morzillo et al. 2007; Tadesse and Kotler 2016; Tadesse and Tafere 2017; Tadesse and Teketay 2017). The analyses were undertaken by using SPSS version 16 .

\section{Results}

\section{Household survey}

A total of 160 persons responded to the questionnaire survey. Majority of the respondents (65\%) were males, and the average age of the participants was 39.8 years with a standard deviation of 9.6. The average family size in a household was 5.5 persons. Regarding the level of education, more than two fifths $(43 \%)$ of the participants went to primary school. Most of the respondents (97\%) engaged in mixed farming, and the average annual income of the participants was about 43,975 Ethiopian Birr (ETB). ${ }^{1}$ On average, the respondents had lived in Bededo Kebele for about 34.1 years. The largest proportion $(84 \%)$ of the participants had livestock. Majority of the participants (84\%) claimed that they had a bigger number of livestock used to serve as insurance during crop failure. Nearly three fourths (74\%) of the respondents did not have enough grazing land. In contrast, the larger percentage $(65 \%)$ of the participants wanted to keep a bigger number of livestock than had at present. Thus, more than half (54\%) of the participants practiced cut and carry system to manage the shortage of fodder for their livestock (Table 1).
Regarding the history of settlement, about three fourths $(76 \%)$ of the participants noted that they had inherited land from their ancestors. Similarly, about $91 \%$ of the respondents planned to stay in the area in the future, and $95 \%$ of the respondents had their own private lands. The average land size was about 0.9 ha. Majority of the respondents (65\%) noted that they had tree planting and growing tradition. More than three fifths $(64 \%)$ of the participants noted that they did not have a shortage of fuelwood. This is because majority of them (65\%) stated that they had access to forest resources. Most of the respondents (96\%) had equal knowledge on community versus state forests governance (Table 1).

Majority of the participants (89\%) noted that they did not know any problem with the existing community forestry in Bededo Kebele. In contrast, an equal proportion of the respondents $(89 \%)$ noted that they knew that there was a problem with the existing state forest governance. Hence, most of the participants noted that the perceived benefits to the local people due to the presence of the community forest included infrastructure development (86\%), source of medicinal plants (84\%), aesthetic and recreational values (83\%), wood products (76\%), and source of fodder for livestock through cut and carry system (73\%). In contrast, majority of the participants briefed that the perceived benefits to the local people due to the presence of the state forest included aesthetic and recreational values (79\%), employment opportunities (59\%), and source of medicinal plants (55\%) (Table 1).

The average distance between the edge of the forests and the residential area of the participants was about $1.67 \mathrm{~km}$. More than half $(64 \%)$ of the respondents noted that they did not get incentives (e.g. seeds, tree seedlings, technical supports, and credits) to plant and grow trees. In contrast, majority of the participants (86\%) noted that they had sufficient market to sell their forest products. Similarly, most of the respondents (91\%) stated that they had enough labour to manage trees/ seedlings planted and grown by them (Table 1 ).

More than half $(64 \%)$ of the respondents noted that they had knowledge on the traditional bylaws that restrict local people and/or livestock from illegally destroying tree seedlings planted and grown in Bededo Kebele. As a result, majority of the participants strongly agreed (83\%) that they had positive attitudes towards the community forestry. In contrast, more than three fifths (70\%) of the respondents noted that they disagreed to have positive attitudes towards the state forest (Table 1).

The multiple linear regression model revealed that several socioeconomic variables significantly affected the views of local people towards the community forest governance. Overall, the multiple linear regression model 
Table 1 Socioeconomic characteristics and descriptive results

\begin{tabular}{|c|c|c|c|}
\hline Variables & Descriptive results & & Proportion (\%) \\
\hline Total sample size $(N)$ & 160 households & & \\
\hline \multirow[t]{2}{*}{ Sex } & Male & & 65 \\
\hline & Female & & 35 \\
\hline Age & Mean $=39.78$ years SD $=9.56$ & & \\
\hline Family size & Mean $=5.53$ persons $; \mathrm{SD}=2.18$ & & \\
\hline \multirow[t]{4}{*}{ Levels of education } & Literate & & 38.40 \\
\hline & Primary education & & 43.12 \\
\hline & Secondary education & & 16.34 \\
\hline & Degree & & 2.14 \\
\hline \multirow[t]{2}{*}{ Occupation type } & Mixed farming & & 96.56 \\
\hline & Government employee & & 3.44 \\
\hline Annual income & Mean $=43,975 \mathrm{ETB} ; \mathrm{SD}=13,964$ & & \\
\hline $\begin{array}{l}\text { Length of the duration of residence in the } \\
\text { area (in years) }\end{array}$ & Mean $=34.13$ years; $S D=11.73$ & & \\
\hline \multirow[t]{2}{*}{ Livestock ownership } & Yes & & 83.55 \\
\hline & No & & 16.45 \\
\hline \multirow[t]{2}{*}{ Had enough grazing land } & Yes & & 25.75 \\
\hline & No & & 74.25 \\
\hline \multirow[t]{2}{*}{ Wanted to keep more livestock in the future } & Yes & & 64.65 \\
\hline & No & & 35.35 \\
\hline \multirow[t]{2}{*}{ Reason to have more number of livestock } & Prestige & & 15.84 \\
\hline & Insurance during crop failure & & 84.16 \\
\hline \multirow[t]{2}{*}{ Had a shortage of fodder for livestock } & Yes & & 73.44 \\
\hline & No & & 26.56 \\
\hline \multirow{10}{*}{$\begin{array}{l}\text { Commonly used methods to manage and } \\
\text { satisfy the forage requirement for } \\
\text { their livestock }\end{array}$} & Free-range grazing & Yes & 13.25 \\
\hline & & No & 86.75 \\
\hline & Cut and carry system & Yes & 39.63 \\
\hline & & No & 60.37 \\
\hline & Transhumance & Yes & 54.33 \\
\hline & & No & 45.67 \\
\hline & Purchasing additional fodder & Yes & 33.53 \\
\hline & & No & 66.47 \\
\hline & Crop residue & Yes & 52.86 \\
\hline & & No & 47.14 \\
\hline \multirow[t]{2}{*}{ History of settlement } & Inherited land from my ancestor & & 76.34 \\
\hline & Settled by my own interest in search of land & & 25.66 \\
\hline \multirow[t]{3}{*}{ Had the plan to stay in the area in the future } & Yes & & 91.38 \\
\hline & Unsure & & 0.00 \\
\hline & No & & 9.62 \\
\hline \multirow[t]{2}{*}{ Had private land ownership } & Yes & & 94.63 \\
\hline & No & & 5.37 \\
\hline Land size & 0.9 ha; $S D=0.73$ & & \\
\hline \multirow[t]{2}{*}{ Had tree planting and growing tradition } & Yes & & 65.31 \\
\hline & No & & 34.69 \\
\hline
\end{tabular}


Table 1 Socioeconomic characteristics and descriptive results (Continued)

Variables
Had a shortage of fuelwood
Had accessibility to forest resources
Had knowledge on community forest
governance
Had knowledge on the state forest
governance
Knew that there was a problem with the
existing community forest governance
Knew that there was a problem with the
existing state forest governance
community forest governance

Perceived benefits to the local people due to state forest governance

Distance between the edge of the forests and the residential area of the respondents $(\mathrm{km})$

Got incentives (e.g. seeds, tree seedlings, technical supports, and credits) to plant and grow trees

Descriptive results

Yes

35.66

No

64.34

Yes

65.12

No

34.88

Yes

95.55

Unsure

0.00

No

4.45

Yes

95.55

Unsure

0.00

No

4.45

Yes

9.38

Unsure

1.56

No

89.06

Yes

89.06

Unsure

1.56

No

9.38

Employment opportunities

46.89

Infrastructure development

85.94

Wood products

75.94

Source of medicinal plants

84.38

Source of fodder for livestock through cut

and carry system

Traditional beehive keeping and source

of honey

25.00

Access to free-range livestock grazing

23.44

Source of income from visiting eco-tourists

31.25

Getting free transport during hardship

periods

Aesthetic and recreational values

82.82

Employment opportunities

59.07

Infrastructure development

15.36

Wood products

10.64

Source of medicinal plants

54.85

Source of fodder for livestock through cut and carry system

Traditional beehive keeping and source

of honey

Access to free-range livestock grazing

Source of income from visiting eco-tourists

Getting free transport during hardship

periods

78.95

Mean $=1.67 \mathrm{~km} ; \mathrm{SD}=3.4$ 
Table 1 Socioeconomic characteristics and descriptive results (Continued)

\begin{tabular}{|c|c|c|}
\hline Variables & Descriptive results & Proportion (\%) \\
\hline \multirow{2}{*}{$\begin{array}{l}\text { Had sufficient market to sell their } \\
\text { forest products }\end{array}$} & Yes & 86.34 \\
\hline & No & 14.66 \\
\hline \multirow{2}{*}{$\begin{array}{l}\text { Had enough labour to manage trees/seedlings } \\
\text { planted and grown by themselves }\end{array}$} & Yes & 91.29 \\
\hline & No & 8.71 \\
\hline \multirow{3}{*}{$\begin{array}{l}\text { Had knowledge on traditional bylaws that } \\
\text { restrict people and/or livestock from illegally } \\
\text { destroying the tree seedlings planted and } \\
\text { grown in the study site }\end{array}$} & Yes & 63.75 \\
\hline & Unsure & 36.25 \\
\hline & No & 0.00 \\
\hline \multirow{5}{*}{$\begin{array}{l}\text { Agree that the respondents had positive } \\
\text { attitudes towards the community forest } \\
\text { governance }\end{array}$} & Strongly agree & 82.81 \\
\hline & Agree & 6.25 \\
\hline & Unsure & 10.94 \\
\hline & Disagree & 0.00 \\
\hline & Strongly disagree & 0.00 \\
\hline \multirow{5}{*}{$\begin{array}{l}\text { Agree that the respondents had positive } \\
\text { attitudes towards the state forest governance }\end{array}$} & Strongly agree & 0.00 \\
\hline & Agree & 18.36 \\
\hline & Unsure & 11.88 \\
\hline & Disagree & 69.76 \\
\hline & Strongly disagree & 0.00 \\
\hline
\end{tabular}

explained about $52 \%$ of the variance on the views of local people towards the community forestry. Similarly, the multiple linear regression model suggested that numerous socioeconomic variables significantly affected the views of local people towards the state forest governance. In general, the model explained about $49 \%$ of the variance on the views of local people towards the state forest (Table 2).

The multiple linear regression model showed that a number of socioeconomic variables significantly affected the attitudes of local people towards the community forest governance. Generally, the multiple linear regression model explained about $47 \%$ of the variance on the attitudes of local people towards the community forestry. Similarly, the multiple linear regression model suggested that numerous socioeconomic variables significantly influenced the attitudes of local people towards the state forest governance. Overall, the model explained about $42 \%$ of the variance on the attitudes of local people towards the state forest (Table 3).

\section{Key informant interviews and focus group discussions Dependence of local people on forests}

Soil and water conservation is one of the most important benefits derived from community and state forests in Tehulederi District that the majority of participants believed. According to the participants, both community and state forests located on the hillsides in Tehulederi District provide soil and water conservation as well as serve as natural habitats for wild animals. Some participants even cited examples of appreciably changed land cover and consequently reduced environmental degradation, gullies healed, springs developed, grass cover that has visibly increased on what was once bare land, and an increase in the availability of wood products, because most of the land was formerly in a degraded condition. This notion of associating the availability of fodder, fuelwood, and construction wood as a result of land rehabilitation was common among youth, men, and women groups. All groups had a similar story when they compared the effects of deforestation and the benefits of reforestation in Tehulederi District. For example, elders expressed their views on community versus state forests by comparing them to the difference between a person with a nice suit and one without. According to their expression, forests represent a memory of the natural environment of the past.

All the participants in the focus group discussions, irrespective of age and sex, noted the advantage of community forest over the conventional forest (i.e. the state managed forest), in that the collection of branches and dried leaves is possible. Specifically, the use of controlled grazing during extended drought periods, and the availability of grass and construction wood from the community forest, has attracted them. According to the women group, the community forest has created a relief for the local people, who previously had to buy fuelwood from other areas for high cost. Most participants across all social groups appreciated the community forest for its role in community development activities and social services, domestic purposes, and as a source of income to support their families during extended 
Table 2 Multiple linear regression model to predict the views of local people towards the community forest governance, and the state forest governance in Tehulederi District

\begin{tabular}{|c|c|c|c|c|c|c|}
\hline \multirow[t]{2}{*}{ Variables } & \multicolumn{3}{|c|}{$\begin{array}{l}\text { Views towards the community forest } \\
\text { governance }\end{array}$} & \multicolumn{3}{|c|}{$\begin{array}{l}\text { Views towards the state forest } \\
\text { governance }\end{array}$} \\
\hline & $\beta$ & $t$ & $P$ value & $\beta$ & $t$ & $P$ value \\
\hline Intercept & -2.54 & -3.85 & - & 1.93 & 3.04 & - \\
\hline Sex $($ female $=1 ;$ male $=2)$ & 0.24 & 1.37 & 0.273 & -0.72 & -1.92 & 0.639 \\
\hline Age & 0.83 & 1.93 & 0.324 & -0.64 & -1.72 & 0.381 \\
\hline Levels of education & 0.27 & $3.38^{* *}$ & 0.001 & 0.63 & $3.45^{* *}$ & 0.001 \\
\hline Family size per household & 0.32 & $3.34^{* *}$ & 0.001 & -0.35 & $-2.97^{* *}$ & 0.002 \\
\hline Annual income (ETB) & -0.43 & $-4.46^{* *}$ & 0.001 & -0.38 & $-3.32^{* *}$ & 0.001 \\
\hline Livestock ownership (no $=1$; yes $=3$ ) & 0.36 & $2.86^{* *}$ & 0.002 & -0.26 & $-3.32^{* *}$ & 0.001 \\
\hline Enough grazing land (no $=1$; yes $=3$ ) & -0.72 & -1.32 & 0.263 & -0.43 & -0.72 & 0.424 \\
\hline $\begin{array}{l}\text { Want to keep more livestock than have at present } \\
(\text { no }=1 \text {; yes }=3 \text { ) }\end{array}$ & -0.23 & $-2.94^{* *}$ & 0.002 & -0.39 & $-2.89^{* *}$ & 0.002 \\
\hline Shortage of fodder for livestock ( $\mathrm{no}=1$; yes $=3$ ) & 0.67 & $3.15^{* *}$ & 0.001 & -0.43 & $-2.94^{* *}$ & 0.002 \\
\hline Length of local residence in the area (years) & 0.34 & 0.67 & 0.543 & -0.25 & -1.32 & 0.253 \\
\hline History of settlement in the area & 0.52 & 0.56 & 0.589 & 0.32 & 0.76 & 0.458 \\
\hline $\begin{array}{l}\text { Plan to stay in the area in the future }(\text { no }=1 ; \\
\text { unsure }=2 ; \text { yes }=3 \text { ) }\end{array}$ & 0.65 & $3.12^{* *}$ & 0.001 & -0.45 & $-2.97 * *$ & 0.002 \\
\hline Private land ownership (no = 1 ; yes $=3$ ) & 0.43 & 1.35 & 0.363 & 0.45 & 0.65 & 0.451 \\
\hline Land size (ha) & 0.11 & 0.44 & 0.671 & 0.42 & 0.44 & 0.635 \\
\hline Tree planting and growing tradition $(\mathrm{no}=1$; yes $=3$ ) & 0.42 & 0.89 & 0.432 & 0.18 & 0.83 & 0.631 \\
\hline Shortage of fuelwood (no = 1; yes $=3$ ) & 0.45 & $3.19^{* *}$ & 0.001 & -0.53 & $-2.89^{* *}$ & 0.002 \\
\hline Accessibility to forest resources (no $=1$; yes $=3$ ) & 0.63 & $3.18^{* *}$ & 0.001 & 0.83 & $3.29^{* *}$ & 0.001 \\
\hline $\begin{array}{l}\text { Distance between the edge of the forests and the } \\
\text { residential area of the respondents }(\mathrm{km})\end{array}$ & 0.14 & 1.34 & 0.236 & -0.38 & -0.82 & 0.527 \\
\hline $\begin{array}{l}\text { Incentives (e.g. seeds, tree seedlings, technical } \\
\text { supports, and credits) to plant and grow trees } \\
\text { (no }=1 \text {; yes }=3 \text { ) }\end{array}$ & 0.62 & $3.15^{* *}$ & 0.001 & 0.78 & $2.96^{* *}$ & 0.002 \\
\hline $\begin{array}{l}\text { Sufficient market to sell their forest products } \\
\text { (no }=1 \text {; yes }=3 \text { ) }\end{array}$ & 0.65 & $2.95^{* *}$ & 0.002 & -0.62 & -1.63 & 0.113 \\
\hline $\begin{array}{l}\text { Enough labour to manage trees/seedlings planted } \\
\text { and grown by themselves (no }=1 \text {; yes }=3 \text { ) }\end{array}$ & 0.18 & $2.94^{* *}$ & 0.002 & -0.36 & -0.89 & 0.351 \\
\hline $\begin{array}{l}\text { Knowledge on the presence of traditional bylaws that } \\
\text { restrict people and/or livestock from illegally } \\
\text { destroying the tree seedlings planted and } \\
\text { grown in the study site (no }=1 \text {; yes }=3 \text { ) }\end{array}$ & 0.84 & $3.17^{* *}$ & 0.001 & -0.64 & $-2.96^{* *}$ & 0.002 \\
\hline
\end{tabular}

Minus sign indicates a negative change in attitudes. Multiple linear regression model: standardized coefficients were reported; ${ }^{* *}$ Significance at the 95\% confidence level. Community forest governance: $R^{2}=0.65$ (Adj. $R^{2}=0.52$ ), df $=21 ; F=8.834$, overall $P<0.0001$. State forest governance: $R^{2}=0.61$ (Adj. $\left.R^{2}=0.49\right), \mathrm{df}=21 ; F=7.956$, overall $P<0.0001$

droughts and hardship periods. Participants in all groups pointed out so far that the government had no share from the outputs of the community forest; they indicated the benefits totally drained to the local people. In contrast, participants of the focus group discussions argued that they were denied access to the state forest. Among elders, one said vividly that 'managing while sustainably utilizing forests'. The women's group gave support, stating that there were instances where women were caught by guards and sent to local courts, where they were fined while found in the state forest. Irrespective of their ages and sex, all the participants in the focus group discussions appreciated their customary rules which constitute an equitable distribution of the benefits and sanctions for malpractices in the community forest. The results of the interview with elders (i.e. men and women) revealed that land shortage was the main bottleneck for planting and growing trees on their own farmlands.

\section{Forest utilization}

According to the key informants, tree harvesting either for private or community development activities and social services requires decision and approval of the community members. They noted that such removal or utilization is limited to construction wood and 
Table 3 Multiple linear regression model to predict the attitudes of local people towards the community forest governance, and the state forest governance in Tehulederi District

\begin{tabular}{|c|c|c|c|c|c|c|}
\hline \multirow[t]{2}{*}{ Variables } & \multicolumn{3}{|c|}{$\begin{array}{l}\text { Attitudes towards the community forest } \\
\text { governance }\end{array}$} & \multicolumn{3}{|c|}{$\begin{array}{l}\text { Attitudes towards the state forest } \\
\text { governance }\end{array}$} \\
\hline & $\beta$ & $t$ & $P$ value & $\beta$ & $t$ & $P$ value \\
\hline Intercept & -3.29 & -2.82 & - & 2.67 & 2.89 & - \\
\hline Sex $($ female $=1 ;$ male $=2)$ & 0.15 & 1.14 & 0.352 & -0.14 & -1.87 & 0.231 \\
\hline Age & 0.24 & 1.09 & 0.651 & -0.16 & -1.48 & 0.432 \\
\hline Levels of education & 0.36 & $2.75^{* *}$ & 0.002 & 0.32 & $2.96^{* *}$ & 0.002 \\
\hline Family size per household & 0.47 & $2.840^{* *}$ & 0.002 & -0.21 & $-3.08^{* *}$ & 0.002 \\
\hline Annual income (ETB) & -0.22 & $-3.10^{* *}$ & 0.001 & -0.16 & $-2.72^{* *}$ & 0.002 \\
\hline Livestock ownership (no = 1; yes $=3$ ) & 0.64 & $2.77^{* *}$ & 0.002 & -0.07 & $-3.36^{* *}$ & 0.001 \\
\hline Enough grazing land (no = 1 ; yes $=3$ ) & -0.14 & -0.66 & 0.523 & -0.15 & -0.62 & 0.543 \\
\hline $\begin{array}{l}\text { Want to keep more livestock than have at present } \\
\text { (no }=1 \text {; yes }=3 \text { ) }\end{array}$ & -0.03 & $-2.86^{* *}$ & 0.002 & -0.06 & $-3.29 * *$ & 0.001 \\
\hline Shortage of fodder for livestock (no = 1; yes $=3$ ) & 0.16 & 1.19 & 0.244 & -0.07 & -0.49 & 0.665 \\
\hline Length of local residence in the area (years) & 0.60 & 0.27 & 0.762 & -0.14 & -0.73 & 0.474 \\
\hline History of settlement in the area & 0.29 & 0.21 & 0.845 & 0.23 & 0.14 & 0.893 \\
\hline $\begin{array}{l}\text { Plan to stay in the area in the future }(\text { no }=1 \text {; } \\
\text { unsure }=2 ; \text { yes }=3 \text { ) }\end{array}$ & 0.42 & $2.92^{* *}$ & 0.002 & -0.10 & $-3.29 * *$ & 0.001 \\
\hline Private land ownership (no = 1 ; yes $=3$ ) & 0.14 & 1.18 & 0.253 & 0.09 & 0.22 & 0.644 \\
\hline Land size (ha) & 0.11 & 0.29 & 0.785 & 0.27 & 0.23 & 0.764 \\
\hline $\begin{array}{l}\text { Tree planting and growing tradition }(\mathrm{no}=1 ; \\
\text { yes }=3 \text { ) }\end{array}$ & 0.01 & 0.69 & 0.651 & 0.07 & 0.65 & 0.726 \\
\hline Shortage of fuelwood (no = 1; yes $=3$ ) & 0.31 & $2.96^{* *}$ & 0.002 & -0.30 & $-2.94^{* *}$ & 0.002 \\
\hline Accessibility to forest resources (no $=1$; yes $=3$ ) & 0.52 & $4.02^{* *}$ & 0.0001 & 0.69 & $3.12^{* *}$ & 0.002 \\
\hline $\begin{array}{l}\text { Distance between the edge of the forests and the } \\
\text { residential area of the respondents }(\mathrm{km})\end{array}$ & 0.15 & 1.17 & 0.254 & -0.04 & -0.31 & 0.768 \\
\hline $\begin{array}{l}\text { Incentives (e.g. seeds, tree seedlings, technical } \\
\text { supports, and credits) to plant and grow trees } \\
\text { (no }=1 \text {; yes }=3 \text { ) }\end{array}$ & 0.11 & $2.64^{* *}$ & 0.002 & 0.23 & $3.38^{* *}$ & 0.001 \\
\hline $\begin{array}{l}\text { Sufficient market to sell their forest products } \\
\text { (no }=1 ; \text { yes }=3 \text { ) }\end{array}$ & 0.54 & $3.30^{* *}$ & 0.001 & -0.33 & -1.33 & 0.199 \\
\hline $\begin{array}{l}\text { Enough labour to manage trees/seedlings planted } \\
\text { and grown by themselves (no }=1 \text {; yes }=3 \text { ) }\end{array}$ & 0.15 & $3.17^{* *}$ & 0.001 & -0.04 & -0.31 & 0.768 \\
\hline $\begin{array}{l}\text { Knowledge on the presence of traditional bylaws that } \\
\text { restrict people and/or livestock from illegally } \\
\text { destroying the tree seedlings planted and } \\
\text { grown in the study site (no }=1 \text {; yes }=3 \text { ) }\end{array}$ & 0.27 & $3.30^{* *}$ & 0.001 & -0.33 & $-3.36^{* *}$ & 0.001 \\
\hline
\end{tabular}

Minus sign indicates a negative change in attitudes. Multiple linear regression model: standardized coefficients were reported; **Significance at the $95 \%$ confidence level. Community forest governance: $R^{2}=0.58$ (Adj. $R^{2}=0.47$ ), $\mathrm{df}=21 ; F=7.934$, overall $P<0.0001$. State forest governance: $R^{2}=0.53\left(\right.$ Adj. $R^{2}=0.42$ ), df $=21 ; F=6.858$, overall $P<0.0001$

fuelwood, through controlled harvesting of mature plantation forest in favour of saplings. For example, during the field visits, coppice stands of Eucalyptus globulus and stumps of Cupressus lusitanica were observed. As the participants in the group discussion noted, a pressing need, especially of very poor farmers, including returning soldiers and resettlers, those whose houses have accidentally been burnt, for the purposes of burial, house construction and farm implements would qualify with the kebele executive committee for the release of poles. According to the participants, the use of dead logs (i.e. standing dead and wind-fallen trees) instead of saplings, and controlled grazing during extended drought periods, was allowed. Fuelwood collection was normally allowed in the community forest as long as the wood was dry. During the survey, no dry wood (i.e. standing or fallen trees) was observed. This was probably an indication of the intensity of fuelwood collection in the community forest. According to the participants in all groups, other non-timber forest products that were collected from the community forest included local medicines, ropes, mushrooms, and 
stones. As to the key informants, forest damage before community management included illegal cutting and grazing activities, farm expansion on the foothills, debarking of live trees, and cutting young trees for fences and sticks. In general, local people showed positive attitudes towards the appropriate use of the community forest in Tehulederi District.

The results obtained from both key informant interviews and focus group discussions (i.e. male, female, and youth groups) confirmed that in the state forest, harvesting of construction wood and poles-even from plantations-forest pasture/grazing, the collection of dead logs (i.e. standing dead and wind-fallen trees), and the collection of dry wood and fuelwood were banned. However, in some cases, villagers were allowed to collect minor forest products, such as traditional medicines, but only for domestic use.

\section{Forest protection}

At present, community forest is the property of the community so that the right to use and protect is vested on the local people. For example, the local people organized guards to monitor adherence to the rules. The community itself pays the salary of the guards. The forest guards patrol the community forest and report offences to the villagers. In addition, each villager takes an interest in what is going on in the community forest. For example, villagers enforce protection through participation and sanctions. These are reinforced by customary rules and are constituted at the village level through the involvement of village elders, who are perceived as the wise persons in the community. Traditional leaders also establish themselves as important stakeholders at community-level undertakings gelagay dagna (i.e. 'mediating juror'). Moreover, local institutions at community and village level played a part in resolving conflicts and constraining wrongdoers. For example, accused persons were given an opportunity to defend themselves and have the right to appeal. The level of penalties varied with the violation of customary rules, which were subject to graded sanctions based on the seriousness and the context of an offence. For example, illicit tree felling, grazing in a non-grazing area, and grazing out of season carried a heavy penalty in the form of deterrent fines, social exclusion, and confiscation of valuable property. However, less destructive activities, such as unauthorized use of the forest for farm implements and collection of branches for fuelwood, carried lighter penalties.

As participants in all focus group discussions argued, the situation has completely changed today. They, as stakeholders, feel a sense of ownership and responsibility for whatever is going on in the community forest. For example, in addition to preventing non-villagers from destroying the forest, community members themselves control each other in preventing the misuse of the community forest. Villagers have to keep each other in check because villagers as collective are responsible for the protection of the community forest.

According to the evidence obtained during the focus group discussions, there are indigenous institutions that facilitate to arrest the person who illegally cut trees in the community forest but not red-handed. Since the number of guards was limited (i.e. each one had to patrol large areas, and illegal cutting often took place at night), the chances of a guard catching the culprit were limited. Hence, local communities expected local institutions to play a part. This included the qire dagna, i.e. the burial association leader, who was expected to bring members together for an oath-taking ceremony mehalla, and people had to walk on the bele, i.e. stick of a sheik swearing that was not involved. If caught, a culprit could be excommunicated through ostracism semona. Some grave disputes could be taken to the Abegar, i.e. spiritual leaders, who are called dem adraqi (i.e. blood dryers) to be dealt with their local court erekebot yifetta.

According to the key informants, the state forest was well protected, since there was little or no disturbance in terms of cutting for fuelwood and building poles. However, in the community forest, there was evidence of footpaths throughout the area, indicating frequent visits by villagers, probably, among other reasons, to collect fuelwood, dried leaves and branches, and herbal medicines. Moreover, grazing has rendered the community forest to have an open floor in some places as there were browsed plants observed in the area.

According to the key informants, all authority concerning management of the state forest was exclusively vested on Tehulederi District forestry department. The management practice so far consisted of guarding the state forest. The participants in all focus group discussions confirmed that they could not harvest any wood products from the state forest. However, the local people could harvest grass for fodder if they had a licence from Tehulederi District Forestry Office. The participants of the focus group discussions confirmed that timber harvesting was banned. However, majority of the participants noted that illegal tree cutting at nights was common in the state forest. For example, according to the key informants, the District Forestry Department filed about 20 cases from 2008 to 2011. About half of those cases were concerned with the possession of illegally obtained poles, while illegal grazing in the state forest accounted for $40 \%$ of the cases and very few cases $(10 \%)$ involved actual illegal tree cutting in the state forest. According to the key informants and participants in all focus group discussions, when the number of cases of illegal activity is considered at the state forest in Tehulederi District, the practice of 
guarding has apparently not yet produced positive results as expected. The Tehulederi District forestry staff also expressed their views on the law enforcement that has been generally constrained by lack of adequate personnel. Participants in the focus group discussions reported that guards patrol only in the nearby areas during the daylight hours; however, those who cut trees tend to operate during the nighttime.

\section{Management and silvicultural schemes}

According to the key informants, since the inception of the community forest management and governance in Tehulederi District, local communities have increased their participation in the management of the community forest. Activities in which they participated include attendance at forest meetings, forest patrols, enrichment planting and replanting trees in open areas, weeding newly planted seedlings, cut and carry of grasses, gap restoration, forest boundary resurveying, raising seedlings in community nursery, coppice thinning (i.e. mainly of Eucalyptus globulus), pruning branches (i.e. mainly of Cupressus lusitanica), and construction of water-harvesting structures (i.e. hillside trenches and micro-basins) on hill slopes. For example, during the field survey, pruned trees of Cupressus lusitanica were observed in the community forest. However, this practice had not yet been adopted in the state forest. For example, during the survey, standing dead and fallen trees were observed in the state forest. This is because the district forestry office so far failed to produce a workable forest management plan to the state forest in Tehulederi District.

\section{Discussion}

\section{Household survey}

Studies on views and attitudes of local people towards community versus state forests governance and management are lacking in Ethiopia (Tesfaye 2011; Tesfaye et al. 2012). This study was the first attempt that examined the views and attitudes of local people towards community versus state forests governance, conservation, and management interventions, identifying sources of conflicts and proposing solutions in future management and policy decisions in Tehulederi District. This is because views and attitudes are understood to be important antecedents of people's behaviour in relation to forest conservation and management (Jotte 1997; Oskamp 1977; Kelboro and Stellmacher 2015). Several studies also considered views and attitudes of local people as a major topic, mostly, in relation to forest conservation and management (e.g. Agarwal 2001; Mehta and Heinen 2001; Kideghesho et al. 2007; Lee et al. 2009; Tesfaye 2011; Tadesse and Tafere 2017; Tadesse and Teketay 2017).

Generally, the present study revealed that local people had positive attitudes towards the community forest governance in Tehulederi District. For example, over $83 \%$ of the respondents agreed to accept and practice community forestry. This is because local people get regulated access to forest resource when it belongs to the community. So, the positive attitudes of local people towards the community forestry may be connected with the perceived benefits (e.g. infrastructure development, source of medicinal plants, wood products, and source of fodder for livestock through cut and carry system) and the various perceived values (e.g. aesthetic and recreational) that local people expect from the community forest. Local people likely obtain various benefits from the forest when it is managed by them. It is widely documented that the decision by local people on whether or not to participate in community forestry is largely determined by perceived values (Elias 2004; Tesfaye et al. 2012; Tadesse and Tafere 2017; Tadesse and Teketay 2017). Resource use conflicts will be also resolved when the forest is managed by the local community (Regassa 2003; Tesfaye 2011; Tesfaye et al. 2012; Kelboro and Stellmacher 2015; Tadesse and Teketay 2017). Furthermore, the presence of community forestry will reduce the burden of illegal exploitation on the state forest. This is because local people will have their own communal forest on which they can have access to the various values of the forest. The presence of community forestry also increases the sense of ownership and use right to the local people so that they will actively participate in managing the forest resource. Hence, local people showed their keen interest in the implementation of community forestry because it helps combat the threatening environmental problems and also obtain other useful forest products. As a result, majority of the respondents expressed their readiness and willingness to participate in community forest management in Tehulederi District.

In contrast, the study showed that about $70 \%$ of the respondents had negative attitudes towards the state forest governance. The negative attitudes of local people towards the state forest could be attributed to the fact that local people may have limited access to the various values of the forest when it is exclusively managed by the state without the direct involvement of local people. This is because local people do not develop a sense of ownership when the forest is exclusively managed by the state (Agarwal 2001; Regassa 2003; Elias 2004; Tesfaye 2011; Tesfaye et al. 2012; Kelboro and Stellmacher 2015). Moreover, such kind of forest management and governance may aggravate antagonistic relationship between the state and the local people, and thus, it can be manifested as forest use conflict.

The findings acquired through the multiple linear regression model revealed that several socioeconomic variables significantly affected the views and attitudes of local people towards the community forestry practiced in Tehulederi 
District. As revealed from their coefficients, those who were more educated, had more number of family size, had livestock, had a shortage of fodder for their livestock, had the plan to stay in the area in the future, had a shortage of fuelwood, had accessibility to forest resources, got incentives (e.g. seeds, tree seedlings, technical supports, and credits) to plant and grow trees, had sufficient market to sell their forest products, had enough labour to manage trees/seedlings planted and grown by themselves, and had knowledge on the presence of traditional bylaws that restrict people and/or livestock from illegally destroying tree seedlings planted and grown in the area significantly had positive views and attitudes towards the community forestry implemented in Tehulederi District. However, those who had high annual income and wanted to keep more livestock than had at present significantly had negative views and attitudes towards the community forestry found in the district (Tables 2 and 3).

One of the possible reasons why more educated people had positive views and attitudes towards the community forestry might be connected with their understanding about the various expected values generated by the community forest. When people have more extended family size, they may be more dependent on forests to meet their basic needs. Hence, they would develop positive views and attitudes towards the community forest. On the other hand, when people have a large number of livestock, but a shortage of fodder, they may satisfy the fodder requirement through cut and carry system from the community forest so that they would develop positive views and attitudes towards the community forest. When respondents have the plan to stay in the area in the future, they may be more concerned about their environment. As a result, they may develop positive views and attitudes towards the community forestry. This is because community forest provides local people with various values (e.g. ecological, economic, and social). One of the benefits of the presence of community forest in Tehulederi District to the local people is the provision of fuelwood. Thus, when the local people have a shortage of fuelwood, it is clear that they will likely develop positive views and attitudes towards the community forest. When local people have access to forest resource, it is obvious that they will develop positive views and attitudes towards the community forestry approach. This is attributed to the fact that the community forest is accessible to local people (e. g. regulated forest use).

When local people are provided with incentives, such as seeds, tree seedlings, technical supports, and credits to plant and grow trees, they will be more interested to participate in community forestry. In return, they will likely develop positive views and attitudes towards the community forestry. When respondents have sufficient market to sell their forest products, it is clear that they will participate in community forest. This is because the different forest products will be sustainably harvested from the community forest (Elias 2004; Tesfaye 2011; Tesfaye et al. 2012). So, it serves as a source of income to local people and leads them to develop positive views and attitudes towards the community forestry (Tadesse and Teketay 2017). When local people have enough labour to manage trees/seedlings planted and grown by them, they will be more interested to participate in community forestry because forest conservation and development absorb a high number of labours (Tadesse and Tafere 2017). Hence, local people will have positive views and attitudes towards the community forestry. When local people have knowledge on the presence of traditional bylaws that restrict people and/ or livestock from illegally destroying tree seedlings planted and grown in the area, they may be more interested to grow trees. This is because the seedlings are protected from illegal anthropogenic disturbances (Tesfaye et al. 2012; Tadesse and Teketay 2017). As a result, local people may have positive views and attitudes towards the community forestry.

However, the increase in negative views and attitudes of local people towards the community forestry with the increase in annual income of the respondents suggested that people with high annual income may not be directly dependent on forest products to satisfy their livelihoods (Elias 2004; Tesfaye et al. 2012; Tadesse and Teketay 2017). As a result, they will likely develop negative views and attitudes towards the community forestry. Moreover, respondents who want to keep more livestock than have at present may need an additional free-grazing area to satisfy the fodder requirement for their livestock. These people may fear that the expansion of community forest in the area will limit the availability of grazing land for their livestock (Tadesse and Teketay 2017). Hence, they will develop negative views and attitudes towards the community forest management.

The results generated through the multiple linear regression model showed that a number of socioeconomic variables significantly affected the views and attitudes of local people towards the state forest governance. As revealed from their coefficients, those who were more educated, had accessibility to forest resources, and got incentives (e.g. seeds, tree seedlings, technical supports, and credits) to plant and grow trees significantly had positive views and attitudes towards the state forest implemented in Tehulederi District. In contrast, those who had more number of family size, had high annual income, had livestock, wanted to keep more livestock than have at present, had a shortage of fodder for their livestock, had the plan to stay in the area in the future, had a shortage of fuelwood, and had knowledge on the presence of traditional bylaws that 
restrict people and/or livestock from illegally destroying tree seedlings planted and grown significantly had negative views and attitudes towards the state forest (Tables 2 and 3 ).

Like the community forestry, when local people are more educated, they will have good knowledge to understand the different values expected from forests. As a result, they will likely develop positive views and attitudes towards the state forest. Moreover, when local people have access to forest resources, they may develop positive views and attitudes towards state forestry. This is because they will likely satisfy their livelihoods from the forest via exploiting inside the state forest. In addition, when local people are provided with incentives (e.g. seeds, tree seedlings, technical supports, and credits) to plant and grow trees by themselves (Tadesse and Teketay 2017), they will develop positive views and attitudes towards the state forest because of the expected benefits generated from the state forest.

The negative views and attitudes of local people towards the state forest with the increase in family size suggested that they will be more worried to feed their family members by increasing their land size. However, when there is a state forest in the area, they will be afraid of facing a shortage of land to expand their crop production. Hence, they may develop negative views and attitudes towards the state forestry. Like the community forestry, when the annual income of local people increases, they will be less dependent on forest products to support their livelihoods (Tadesse and Teketay 2017). As a result, they will probably develop negative views and attitudes towards the state forest. When local people have livestock, or want to keep more livestock than have at present, or have a shortage of fodder for their livestock, they may need a free-grazing area to meet the forage requirement for their livestock (Tesfaye 2011). However, local people might be punished if they are arrested while illegally grazing their livestock inside the state forest. As a result, they will develop negative views and attitudes towards the state forest.

When local people have the plan to stay in the area in the future, they may be more concerned about their environment to satisfy their livelihood. One of the means by which they can meet their livelihood is through agriculture. So, they need more land to expand farming activities. If there is a state forest in the area, it may in turn limit their access to expand their agricultural land (Elias 2004; Tesfaye 2011). As a result, they may develop negative views and attitudes towards the state forest. Moreover, if local people have a shortage of fuelwood, they may not be interested to see the state forest in the area. This is because they are usually denied by law to collect fuelwood in the state forest. As a result, they may develop negative views and attitudes towards the state forest. Moreover, when respondents have knowledge on the presence of traditional bylaws that restrict people and/or livestock from illegally destroying tree seedlings planted and grown in the state forest, they will be afraid of the punishment if they are arrested while committing illegal activities (i.e. livestock grazing, fuelwood collection, and tree cutting) (Elias 2004; Tadesse and Tafere 2017; Tadesse and Teketay 2017). Hence, they will likely develop negative views and attitudes towards the state forest.

Generally, views and attitudes of local people towards community and state forests can be positively influenced by increasing their knowledge and benefits (Agarwal 2001; Elias 2004; Tesfaye 2011; Tesfaye et al. 2012; Kelboro and Stellmacher 2015; Tadesse and Teketay 2017). More importantly, public awareness programmes and conservation education can assist in improving the views and attitudes of young people towards community and state forests governance and management. Promoting direct participation of local residents in decision-making and implementation of appropriate community and state forests strategic plans can also mitigate potential conflicts and assure longterm public supports towards the management of forests. Hence, by comparing views and attitudes quantified and presented in this baseline study as well as results from future replication of this study, researchers can provide relevant quantitative and qualitative information for decision-makers and forest conservation managers to deal with potential conflict of interests between community versus state forests and the needs of the local people.

\section{Key informant interviews and focus group discussions Dependence of local people on forests}

In developing countries, such as Ethiopia, majority of local people are directly dependent on forest resources to meet their livelihoods, including fuelwood, food, fodder, timber, honey, and charcoal production (EFAP 1994; Evangelista et al. 2007). Unlike the communitybased forestry, the findings of this study suggested that a protectionist approach to forest conservation and management by the state may marginalize forestdependent households, without providing them with alternatives. This may eventually result in inequity within communities and could also be a potential threat to the long-term sustainability of the forest resources especially in the developing countries (Bekele 2003). For example, a lack of forest products/timber availability, resulting from a protectionist approach by the state, may place the remaining forest areas under increasing extraction pressure, as communities seek alternatives sites for timber collection. Ezra and Kassahun (1988) also reported that the uncertainty about ownership and rights of the use of tree plantations contributed to the low performance of the forestry development programme in Ethiopia. A sense of forest 
ownership or secured user rights to forests is critical for active engagement of local communities in forest resource management (Ellsworth and White 2004). Hence, ensuring the sustainable management of the remaining forest resources in Ethiopia needs appropriate policies, which take into consideration the historical and legitimate rights of the local communities (EFAP 1994).

\section{Forest utilization}

Under the influence of tribal kings or elders, different communities practice varying systems of sustainable forest production through practicing coppicing, low-impact harvesting, and rotational harvesting (Mandondo 2003). In the present study, the state forest was not able to meet the needs of the local community, neither regarding to the community development activities and social services nor for farmers' consumption needs, particularly for construction wood, firewood, and forest pasture during droughts, despite its stable structure (i.e. healthy forest) and higher basal area (i.e. biomass) (Woldie and Tadesse, unpublished data). One of the reasons for this situation was the strict protection-oriented, passive non-participatory approach adopted by the state in the management of the state forest in Tehulederi District. According to Bekele (2003), such a conventional approach in the management of forests is common in Ethiopia. Lemenih and Bekele (2007) also noted that the state monopoly of property ownership degraded not only the forest access rights of local people in Ethiopia but also their ancient traditional systems (e.g. the Gada system of the Borana Oromo) of forest resource management, including local knowledge and institutions.

There could be several reasons for the adoption of the protectionist approach in the management of forests by the state (i.e. by the district forestry department). However, concerns over the risk of degrading the forest resource through unsustainable utilization may be the most important factor contributing to this approach in Ethiopia (Admassie 1995; Kelboro and Stellmacher 2015). In this context, optimum utilization of the state forest, with due consideration to the requirements of the local community, is one of the key issues that call for consideration in the management of the state forest. This could be achieved through effective training and extension activities, which increase the confidence of the state on yield-based active forest management. According to Agrawal and Clark (2000), if local communities are effectively involved in forest conservation, the benefits they receive would create incentives for them to become good stewards of natural resources.

The protectionist approach of the state forest governance has not only affected the general availability of the forest products to the communities but may also have negative implications for the management of the community forest. Previous studies also suggested that the type of forest ownership influences its status, conditions, and way of its management (Wily and Mbaya 2001; Kelboro and Stellmacher 2015). The focus group discussions revealed that the negative impacts arising from such an approach are more directed towards the poor farmers, particularly landless households, because there will be less opportunity for private forestry to supplement the forest products obtained from the community forest. Moreover, a lack of disposable income will prevent a household from purchasing the required forest products from a secondary source (Wily and Mbaya 2001).

\section{Forest protection}

Despite the effective role of local institutions in controlling free-range livestock grazing, illicit tree felling, and sharing benefits, the agreements and arrangements are informal and not legally binding (Heinen and Mehta 1999; Kelboro and Stellmacher 2015). So, clarification and enforcement of the rights and responsibilities of all stakeholders are essential. For example, a good policy of environment protection and legal framework facilitates enforcement mechanisms with gradual sanctions. Thus, legal recognition of local institutions and endorsement of their bylaws are essential elements to encourage investment in forest resource management (Heinen and Mehta 1999; Bekele 2003; Kelboro and Stellmacher 2015). For example, a clear definition of rights, returns and responsibilities, and adequate incentives are important for the sustainability of people-centred management of natural resources (Kajembe et al. 2005). A case study in Tanzania showed that the government alone was not able to protect and manage the forest resources sustainably (Blomley 2006). Hence, establishing legal institutions and governance that enhance community involvement in forest management, together with clarification of ownership and user rights, is seen as one of the optimal solutions (FAO 2000; Kelboro and Stellmacher 2015) to promote forest development and sustainable utilization in Tehulederi District and elsewhere in Ethiopia.

\section{Management and silvicultural schemes}

Traditional resource management system contained precise controlling instruments and mechanisms, based on shared norms, and values and regulations, based in turn on community-specific customary laws (Admassie 1995; Pankhurst 2001; Lemenih and Bekele 2007; Kelboro and Stellmacher 2015). Community-based forest management system reduces forest resources degradation while improving rural livelihoods (Kellert et al. 2000; Malla et al. 2003). For example, in the early 1980s, the Nepalese government realized the role and value of the local communities in sustainable forest management and began community forestry as a forest 
management system (Joshi 1997). In the present study, it was observed that community-based forestry enabled local communities to adopt the customary forest management regime in Tehulederi District. Because of their knowledge and traditional practices, indigenous people and their communities probably may have a vital part to play in the management of the nearby forests; local institutions may make better use of the forests (Heinen and Mehta 1999; Elias 2004), manage them more sustainably, and contribute more equitably to their livelihoods than the state forest department. Similar findings in Tanzania were also suggested by Kajembe et al. (2003) that community-based forestry initiatives that start with 'grassroots', rather than being governmentled, are usually more resilient and successful in the management of forest resources.

On the other hand, if communities are not involved in active forest management, it is likely that they will harvest the forests at an unsustainable rate. Moreover, illegal forest encroachment becomes intense when local people are denied their access to forests (FAO 2000; Kelboro and Stellmacher 2015; Tadesse and Teketay 2017). The results of the present study suggested that when local stakeholders participate in decision-making and get benefits, this may have given local people a sense of ownership and use right, and an understanding how to realize sustainability and direct economic benefits from their community forest. Similar results were reported by Odera (2004) that in many countries, people have developed positive attitudes towards increased stakeholder participation in forest management, generally banking on an enhanced flow of benefits and forest contributions to the local livelihoods. Murphree (2000) also exemplified his findings that rural people and communities become more responsible with respect to forest management, as their rights become clearer and the benefits are significant; this in turn creates favourable stakeholder relations in forest management and governance. Ostrom (1992) argued that for resource users to participate in management initiatives, the benefits should exceed the costs.

The present study suggested that besides their direct contribution to forest management and silvicultural activities, such as forest patrols, enrichment planting and replanting trees in open areas, weeding newly planted seedlings, gap restoration, forest boundary resurveying, raising seedlings in community nursery, coppice thinning, and pruning branches, local people carried out land management activities in community forest, including construction of water-harvesting structures (i.e. hillside trenches and micro-basins) on hill slopes. There are several convincing examples where local communities have shown great appreciation towards forests as they have acquired through community-based forest management, by providing their labour voluntarily and keeping degraded forest sites for long-term benefits so as to allow enhanced future benefits (Kajembe et al. 2003). However, Campbell et al. (2003) argued that, with the declining of the joy from the satisfaction of recapture forests, some local communities have begun to show impatience with perpetuated central government's control over forests. They find government's in-kind support, including contributions to community infrastructure development, is limited and inadequate.

\section{Conclusion}

In developing countries, such as Ethiopia, forest conservation and management by exclusively restricting human activities cause conflicts between the local communities and the state and, in turn, lead to further forest degradation. This is because natural resources, such as water and forests, are not only the socioeconomic buffer of the poor, but they are also essential elements for the livelihood development of the rural communities. The change in forest management from fully centralized control (e.g. the state forest governance) of the resource towards a more participatory approach (e.g. the community forestry) had many positive impacts on the forest and the local people as evidenced by the findings of the present study where distinct difference was observed between community and state forests in Tehulederi District. While emphasizing views and attitudes of local people towards community versus state forests, the present study contributed to improved knowledge on human dimensions. This may motivate forest managers to include local people during the process of formulating community versus state forests management strategies and plans. In the context of community-based forest management, participants' understanding or view of the purpose and the implication of the arrangement with respect to their interest and thus the attitudes they form influence the willingness and commitment for its implementation. This is a useful result for forest conservation managers, land use planners, and policy- and decision-makers because the change in views and attitudes of the rural people towards community forestry is important for conservation and sustainable utilization of the remnant forest resource in Tehulederi District and elsewhere.

In the present study, the community forestry showed effective management, as it is evident by relatively higher forest health (e.g. good forest structure maintained through regulated use). Hence, the study revealed that, compared to the state forest, local people had more positive views and attitudes (83\%) towards the community forest governance. Even though forests have been classified into community- and state-owned, local people are aware of the multi-functioning and 
have gained multiple benefits from them. Under community forestry management, local people have more access to resources and more forest-related activities for improving the forest status and productivity. The community forestry in Tehulederi District is not only implemented for the benefits of the communities themselves, but it is also used to complement state and public purposes of conservation. The positive changes in forest status provide evidences of ecological sustainability of the resource, and the findings also signify to some extent the success of forest conservation efforts by the local communities. As the community and state forests included in the present study are situated in very similar ecological and socioeconomic settings, the results thus provide evidence for the relative advantage of community forestry over the complete government control of the forest resource.

This study investigated appropriate management strategies and techniques about community versus state forests in Tehulederi District. This may assist forest managers, local communities, and private and public sectors in addressing opportunities and challenges for conserving and managing forests. Other than academic purposes, it is believed that the findings of this study generated quantitative and qualitative scientific information for policy-makers and planners that guide them towards better and more informed decision-making for the establishment of community versus state forests governance and implementation that is geared towards communal forest management and, thereby, to achieve the broader goal of poverty reduction in Ethiopia. Therefore, effective conservation and sustainable use of forests need the full involvement of many stakeholders, including the local communities.

Based on the findings of the present study, the followings are recommended:

- Operational strategies developed by the local communities are not static but have evolved through pressure and internal need under the changing circumstances. Therefore, it is necessary to build up the body of new knowledge on community forest management that recognizes the balance of ecological and sociocultural bases and roles of communities in forest management in response to their need for short-term and long-term benefits.

- Forest development strategies and management plans should be based on site-specific biophysical conditions, historical background, and dynamism of communities, in association with the external circumstances.

- In forest areas that are under collective management or accessed by the communities in the nearby areas to maintain their livelihood, support to formulate bylaws would be an effective strategy.
- There might be uncertainty concerning a community's capacity to manage forest resources sustainably. Therefore, external or co-monitoring mechanisms should be developed to ensure that they are managed by many stakeholders, including the local communities.

- Collaboration among concerned bodies, namely governmental and non-governmental organizations, researchers, extension workers, administrative bodies, and local people, is quite essential for the sustainable management and utilization of the forest resources in study site and elsewhere in Ethiopia.

- Restoring the degraded forests, which provide wood and non-wood products for a large proportion of the rural population in Tehulederi District, is a critical issue as they also contribute to environmental services and sustainability.

- Increasing the knowledge and awareness level of the local communities about community versus state forests governance, management, and sustainable utilization is crucial to introduce and effectively implement those forestry practices.

- Farmers should be encouraged to involve in problem definition, the design of possible forest management solutions, and evaluation of the proposed technological solutions.

- Integrating indigenous knowledge with modern conservation approaches in the planning and implementation process is crucial to improve and promote local participation in conservation and management of forests. This is because indigenous knowledge not only provides relevant information on the use of the forest resource but also contributes valuable information on how to maintain and conserve it.

- Impact of changes in forest product availability on different socioeconomic groups (i.e. rich, medium, and poor people) within the community should be further studied in the future.

- Private forestry (i.e. is a forest development activity which is practiced and managed by an individual farmer or a person on his/her own private land or plot) constitutes an important source of subsistent products in Tehulederi District, but how private forestry is emerging to cope with the challenges arising from the change in dependencies of rural households between community, government, and private resources is not known yet. So, this is another important area to be studied in the future.

\section{Endnotes}

${ }^{11} 21.43 \mathrm{ETB}=1 \mathrm{USD}$ at the time when this study was conducted. 


\section{Acknowledgements}

The authors would like to thank Drs. Mulugeta Zewdie and Melaku Bekele for their invaluable comments at the earlier period of this research. The authors also warmly thank Dr. Jeremy Flower for editing the earlier version of the manuscript which helped much to improve the final version. The authors are indebted to thank Zeray Tadesse, Demere Hailu and the local farmers in the Bededo Kebele who helped to handle the field data collection. The staff members in Tehulederi District, particularly at the office of Agriculture deserve warm acknowledgments. We also thank the editor-inchief of Ecological Processes and the two anonymous reviewers whose comments helped much to improve the earlier version of the manuscript.

\section{Funding}

The authors would like to forward their gratitude to the Swedish International Development Agency (SIDA), Demand Driven Action Research (Horne AfricaRegional Environment Network) and Amhara National Regional State Bureau of Agriculture (ANRS-BOA) for all sources of funding that helped the design of the study, field data collection, analyses, interpretation of the data, and writing the manuscript.

\section{Availability of data and materials}

Please contact the authors for data requests.

\section{Declarations}

Not applicable in each section

\section{Authors' contributions}

BAW designed and conducted the field research, analyzed the data, and drafted the manuscript. SAT interpreted the results and helped in writing the manuscript. Both authors read, revised, and approved the final manuscript.

\section{Ethics approval and consent to participate}

Not applicable in this section.

\section{Consent for publication}

Not applicable in this section.

\section{Competing interests}

The authors declare that they have no competing interests.

\section{Publisher's Note}

Springer Nature remains neutral with regard to jurisdictional claims in published maps and institutional affiliations.

\section{Author details}

'Sustainable Natural Resources Management Association (SUNARMA), P.O. Box 11, Debre Berhan, Ethiopia. ${ }^{2}$ Department of Natural Resources Management, College of Agriculture and Natural Resource Sciences, Debre Berhan University, P.O. Box 445, Debre Berhan, Ethiopia.

Received: 26 September 2018 Accepted: 27 December 2018 Published online: 01 February 2019

\section{References}

(EFAP) (Ethiopian Forestry Action Program) (1994) Final report. Vol. 3: issues and actions. EFAP Secretariat, Addis Ababa

Abiyu A (2005) Effects of different restoration strategies on vegetation and soils in Tehuledere district, South Wollo, Ethiopia. MSc Thesis. Institute of Forest Ecology, University of Natural Resources and Applied Life Sciences, Vienna

Admassie $Y$ (1995) Twenty years to nowhere - property rights, land management and conservation in Ethiopia. PhD Dissertation. Uppsala University, Uppsala, Sweden

Agarwal B (2001) Participatory exclusions, community forestry and gender: an analysis for South Asia and a conceptual framework. World Dev 29:1623-1648

Agrawal A, Clark CG (2000) Communities and environment. Rutgers University Press, New Brunswick

Ameha A, Larsen HO, Lemenih M (2014) Participatory forest management in Ethiopia: learning from pilot projects. Environ Manag 53:38-54

ANRS-BOA (Amhara National Regional State Bureau of Agriculture) (1999) Forest Development, Conservation and Utilization Proclamation No 002/1999. ANRS-BOA (Amhara National Regional State Bureau of Agriculture), Bahir Dar
Bekele M (2003) Forest property rights, the role of the state, and institutional exigency: the Ethiopian experience. Doctor's dissertation. Swedish University of Agricultural Sciences, Sweden

Bekele T (2000) Plant population dynamics of Dodonaea angustifolia and Olea europaea ssp. cuspidata in dry afromontane forests of Ethiopia. Acta Universitatis Upsaliennsis. Comprehensive Summaries of Uppsala Dissertations from the Faculty of Science and Technology, Uppsala, p 559.47

Blomley T (2006) Mainstreaming participatory forestry within the local government reform process in Tanzania. Gatekeeper series 128. International Institute for Environment and Development, London

Campbell BM, Shackleton S, Wollenberg E (2003) Overview of institutional arrangements for managing woodlands. In: Kowero G, Campbell BM, Sumaila UR (eds) Policies and governance structures in woodlands of Southern Africa. CIFOR, Bogor. Carelica 14, pp 1-388

Cohen L, Manion L, Morrison K (2000) Research methods in education, 5th edn RoutledgeFalmer, London

Dejene A (1990) Environment, famine and politics in Ethiopia: a view from the village. Lynne Rienner, London, p 128

Elias K (2004) People's perception of forest and livelihood in joint forest management area, Chilimo, Ethiopia. Unpublished MSc thesis. Swedish University of Agricultural Sciences, Skinnskatterberg

Ellsworth L, White A (2004) Deeper roots: strengthening community tenure security and community livelihoods. Ford Foundation. Available at http:/ rightsandresources.org/wp-content/exported-pdf/ ellsworthwhite2004deeperroots.pdf. Accessed 20 Aug 2018

Evangelista P, Swartzinski P, Waltermire R (2007) A profile of the mountain nyala (Tragelaphus buxtoni). African Indaba 5:1-48

Ezra M, Kassahun B (1988) A review of the community forestry programme and an evaluation of its achievements: a socio-economic survey. SIDA, Addis Ababa

FAO (Food and Agriculture Organization) (2000) Community involvement in forest management: first experiences from Tanzania. The Gologolo Joint Forest Management Project: a case study from the West Usambara Mountains, by S. Iddi. In: Proceedings of the International Workshop on Community Forestry in Africa. 26-30 April 1999, Banjul, the Gambia, pp 153-162

Friis I (1992) Forests and forest trees of northeast tropical Africa. Kew Bulletin Additional Series XV:1-396

Heinen JT, Mehta JN (1999) Conceptual and legal issues in the designation and management of conservation areas in Nepal. Environ Conserv 6:21-29

Hren D, Lukic IK, Marusic A, Vodopivec I, Vujaklija A, Hrabak M, Marusic M (2004) Teaching research methodology in medical schools: students' attitudes towards and knowledge about science. Med Educ 38:81-86

Joshi AL (1997) Community forest in Nepal: 1978-2010

Jotte Z (1997) Folklore and conservation in Nigeria: using PRA to learn from elders. Ichire Ojating and the students of the Federal University of Agriculture, London

Kajembe GC, Monela GC, Mvena ZSK (2003) Making community-based forest management work: a case study from Duru-Haitemba village forest reserve, Babati, Tanzania, in policies and governance structures in woodlands of southern Africa, edited by G Kowero, BM Campbell \& UR Sumaila. Centre for International Forestry Research, Jakarta, pp 16-27

Kajembe GC, Nduwamungu J, Luoga EJ (2005) The impact of community-based forest management and joint forest management on the forest resource base and local people's livelihoods: case studies from Tanzania. Centre for Applied Social Sciences and Programme for Land and Agrarian Studies. CASS/PLAAS Occasional Paper Series No. 8

Kelboro G, Stellmacher T (2015) Protected areas as contested spaces: Nech Sar National Park, Ethiopia, between 'local people', the state, and NGO engagement. Environ Dev 16:63-75

Kellert SR, Mehta JN, Ebbin SA, Lichtenfeld LL (2000) Community natural resource management: promise, rhetoric, and reality. Journal of Society and Natural Resources 13:705-715

Kideghesho J, Roskaft RE, Kaltenbornb P (2007) Factors influencing conservation attitudes of local people in Western Serengeti, Tanzania. Int J Biodivers Conserv 16:2213-2230

Lee TM, Sodhi NS, Prawiradilaga DM (2009) Determinants of local people attitudes towards conservation and the consequential effects on illegal resource harvesting in the protected area of Sulawesi (Indonesia). J Environ Conserv 36:157-170

Lemenih M, Bekele M (2007) Best practices, lesson learnt and challenges encountered the Ethiopian and Tanzanian Experiences. FARM-Africa/SOSSahel. Available at https://theredddesk.org/sites/default/files/resources/pdf/ PFM\%20lessons\%2C\%20challenges\%20and\%20best\%20practices.pdf. Accessed 20 July 2018 
Malla YB, Hari RN, Branney PJ (2003) Why aren't poor people benefiting more from community forestry. J For Livelihood 3:78-92

Mandondo A (2003) Situating Zimbabwe's natural resource governance systems in history. CIFOR. Available at https://www.cifor.org/library/716/. Accessed 18 Aug 2018

Mehta JN, Heinen JT (2001) Does community-based conservation shape favorable attitudes among locals? An empirical study from Nepal. Environ Manag 28:165-177

Morzillo AT, Mertig AG, Garner N, Liu J (2007) Resident attitudes towards black bears and population recovery in East Texas. Hum Dimens Wildl 12:417-428

Murphree MW (2000) Community based conservation: old ways, new myths and enquiring challenge in College of African Wildlife Management. African Wildlife Management in the New Millennium, Mweya

Odera J (2004) Lessons learnt on community forest management in Africa. National Museums of Kenya, Nairobi, p 76

Oskamp S (1977) Attitudes, values and opinions. Prentice Hall, Englewood cliffs

Ostrom E (1992) The rudiments of a theory of the origins, survival and performance of common property institutions. In: Bronkey D (ed) Making the commons work: theory, practice and policy. ICS Press, San Francisco

Pankhurst A (2001) State and community forests in Yegof, South Wollo, Ethiopia. MARENA working paper, no. 6. Brighton: University of Sussex. Paper presented at the second workshop on participatory forestry in Africa, 18-22 February 2002, Arusha, Tanzania

Paudyal BR (1996) Comparison of benefit-sharing arrangements in joint forest management in India and community forestry in Nepal: Some lessons learned. Proceedings of the Social Forestry Seminar, Australian National University, 18 June 1996

Regassa A (2003) Impact of WAJIB forest management on structure and regeneration of indigenous tree species the case of Adaba-Dodola regional forest priority area. MSc thesis. Swedish University of Agricultural Sciences and Wondo Genet College of Forestry, Wondo Genet, p 40

Siraj M, Zhang K, Xiao W, Bilal A, Gemechu S, Geda K, Yonas T, Xiaodan L (2018) Does participatory forest management save the remnant forest in Ethiopia? Proceedings of the National Academy of India Section B. Biol Sci 88:1

Stahl M (1990) Environmental degradation and political constraints in Ethiopia. Disaster 14:140-150

Tadesse SA, Kotler BP (2016) Attitudes of local people towards the mountain nyala (Tragelaphus buxtoni) in Munessa, Ethiopia. Afr J Ecol 54:488-499

Tadesse SA, Tafere SM (2017) Local people's knowledge on the adverse impacts and their attitudes towards growing eucalyptus woodlot in Gudo Beret Kebele, Basona Worena District. Ethiopia Ecol Processes 6:37

Tadesse SA, Teketay D (2017) Perceptions and attitudes of local people towards participatory forest management in Tarmaber District of North Shewa Administrative Zone, Ethiopia: the case of Wof-Washa Forest. Ecol Process 6:17

Tekle K (1999) Land degradation problems and their implications for food shortage in South Wollo, Ethiopia. Environ Manag 23:419-427

Tesfaye Y (2011) Participatory forest management for sustainable livelihoods in the Bale Mountains, Southern Ethiopia. Doctoral dissertation. Swedish University of Agricultural Sciences, Uppsala, p 109

Tesfaye Y, Anders R, Folke B (2012) Attitudes of local people towards collective action for forest management: the case of PFM in Dodola area in the Bale Mountains, Southern Ethiopia. Int J Biodiver Conserv 21:245-265

Wily LA (2002) Participatory forest management in Africa. An overview of progress and issues. Available at http://www.fao.org/docrep/pdf/006/Y4807B/ Y4807B03.pdf. Accessed 25 August 2018

Wily LA, Mbaya S (2001) Land, people and forests in eastern and southern Africa at the beginning of the 21st century: the impact of land relations on the role of communities in forest future. Forest and Social Perspectives in Conservation, IUCN Eastern Africa Programme, the World Conservation Union. Available at https://portals.iucn.org/library/efiles/documents/2000-01907.pdf. Accessed 15 Aug 2018.

Woltamo T (1997) The development of gender knowledge and gender typed beliefs in preschool years. MSc thesis. Addis Ababa University, Addis Ababa

\section{Submit your manuscript to a SpringerOpen ${ }^{\circ}$ journal and benefit from:}

- Convenient online submission

- Rigorous peer review

- Open access: articles freely available online

High visibility within the field

- Retaining the copyright to your article

Submit your next manuscript at $\boldsymbol{\nabla}$ springeropen.com 